\title{
DISIPLIN PASAR DAN MORAL HAZARD BANK
}

\section{Nur Ariani Aqidah}

Fakultas Ekonomi dan Bisnis Islam Institut Agama Islam Negeri (IAIN) Palopo

Email : $\underline{\text { n.arianiaqidah@gmail.com }}$

\begin{abstract}
This paper aims to explain the relationship between market discipline and moral hazard banks. Market discipline is one of the three pillars formed by the Basel Committee in improving banking performance and transparency through supervision carried out by depositors. While moral hazard is high risk taking by the bank. Market discipline and bank moral hazard can be understood using agency theory.
\end{abstract}

Keywords: Market Discipline, Moral Hazard, Bank, Agency Theory

\section{Abstrak}

Tulisan ini bertujuan untuk menjelaskan tentang keterkaitan antara disiplin pasar dan moral hazard bank. Disiplin pasar merupakan salah satu dari tiga pilar yang dibentuk oleh Basel Committee dalam meningkatkan kinerja dan transparansi perbankan melalui pengawasan yang dilakukan oleh para deposan. Sedangkan moral hazard adalah pengambilan risiko yang tinggi oleh pihak bank. Disiplin pasar dan moral hazard bank dapat dipahami dengan menggunakan teori keagenan (agency theory).

\section{Kata Kunci : Disiplin pasar, Moral Hazard, Bank, Teori Keagenan}

\section{PENDAHULUAN}

Bank adalah sebuah badan usaha yang berfungsi sebagai lembaga keuangan intermediasi (intermediary institution) yang menghimpun dana dari masyarakat dalam bentuk simpanan kemudian menyalurkan kepada masyarakat yang memerlukan tambahan dana dalam bentuk kredit. Karena fungsi bank sebagai lembaga intermediasi maka industri perbankan merupakan salah satu industri yang paling berperan dalam memajukan dan menjaga kestabilan sistem perekonomian suatu negara. Oleh karena itu, aset bank dalam bentuk kepercayaan masyarakat sangat penting dijaga untuk mencegah terjadinya bank run. ${ }^{l}$

Basel Commitee (2001) membangun tiga pilar yang akan memperkuat kestabilan sistem keuangan di suatu negara yaitu persyaratan kecukupan modal

${ }^{1}$ Bank run adalah kondisi dimana bank mengalami kerugian dari penarikan deposito yang dilakukan oleh masyarakat yang dipicu oleh rasa takut masyarakat bahwa bank akan mengalami kegagalan finansial sehingga masyarakat akan menarik dananya untuk menghindari kerugian(Diamond dan Dybvig, 1983). 
minimun bank, tinjauan pengawasan dan disiplin pasar. Pilar ketiga yaitu disiplin pasar (market discipline) untuk menguatkan kebijakan modal dan usaha-usaha pemerintah di suatu negara baik meningkatkan dan kesehatan bank maupun dalam menjaga sistem stabilisasi keuangan. Disiplin pasar telah menjadi topik penelitian dalam sektor keuangan sejak tahun 1970an (Flannery, 2001). Beberapa yang telah meneliti kemampuan disiplin pasar dalam mengatur layanan keuanganfokus pada perbankan diantaranya yaitu Mertinez-Peria dan Schmukler (2001) dan King (2008).

Ada beberapa definisi disiplin pasar yang saat ini digunakan. Contohnya dalam literatur perbankan, ada kesepakatan luas bahwa disiplin pasar mencakup dua komponen (Flannery, 2001; Bliss \& Flannery, 2002: Forssbaeck, 2009; Eling, 2011). Komponen yang pertama yaitu kemampuan dari pelaku-pelaku pasar untuk menilai secara tepat kondisi sebuah perusahaan (pengawasan) dan yang kedua yaitu kemampuan pelaku pasar untuk mempengaruhi tindakan-tindakan dari manajemen perusahaan sebagai sebuah cara yang mencerminkan penilaian (influencing). Disiplin pasar dalam perbankan merupakan tindakan yang dilakukan baik oleh pemegang saham, depositor maupun kreditor.

Disiplin pasar merupakan cara yang paling efektif dalam mengurangi moral hazard yang dilakukan oleh perbankan (IADI, 2013). Depositor, debtholder dan pemegang saham akan memaksa bank untuk menjalankan bisnisnya dengan cara yang aman, sehat dan efisien. Tujuan dari disiplin pasar ini adalah untuk memastikan bahwa bank-bank memberikan informasi yang jelas dan akurat tentang status keuangan mereka kepada pasar (Caldwell, 2007), sehingga pelaku pasar atau depositor akan mengambil langkah pendisiplinan terhadap bank yang memiliki status keuangan yang buruk yang disebabkan salah satunya karena adanya pengambilan risiko yang berlebih oleh bank pada aktivitas bisnisnya.

Penelitian ini akan mengkaji lebih jauh lagi tentang peran disiplin pasar dalam mengurangi moral hazard bank. Disiplin pasar dibutuhkan untuk mengawasi bank dari perilaku moral hazard bank yang tercermin dalam pengambilan risiko yang 
berlebihan. Penelitian yang dilakukan oleh Nier dan Bauman (2006) yang tentang keefektifan disiplin pasar dalam membatasi pengambilan risiko berlebihan oleh bank, menemukan hasil bahwa moral hazard ada pada 729 bank yang dijadikan sampel dan disiplin pasar memainkan peran penting dalam mengurangi risiko kebangkrutan bank. Park dan Peristiani (2007) membangun kerangka dasar penelitian empiris untuk menguji apakah depositor merespon pengambilan risiko bank yang tinggi dengan menarik depositonya atau dengan meminta kenaikan suku bunga. Park dan Peristiani (2007) menemukan fakta bahwa disiplin pasar bisa dilihat dari pertumbuhan deposito, dimana depositor akan menarik simpanannya dari bank yang memiliki risiko berlebih dan permintaan kenaikan suku bunga simpanan.

\section{PEMBAHASAN}

\section{Teori Keagenan (Agency Theory)}

Peran disiplin pasar dalam mengurangi moral hazard bank dapat dipahami dengan menggunakan teori keagenan (agency theory). Teori keagenan pertama kali diperkenalkan oleh Jensen dan Meckling (1976) yang menyatakan bahwa agent dan principal mempunyai kepentingan masing-masing dalam memaksimalkan utilitasnya. Dalam literatur perbankan (Kane, 1988; Keeley, 1990 Barth, 1991; White, 1991; Demsetz; 1997) telah ditekankan dua tipe agency problem. Pertama, terbatasnya hutang, memberikan dorongan bagi pemegang saham untuk mengambil alih kekayaan dari bondholders dengan meningkatkan risiko. Hal ini terjadi ketika deposan diberikan jaminan keamanan dari kerugian pengambil risiko oleh bank. Sehingga tidak ada pengawasan dari deposan terhadap pengambilan risiko oleh bank dikenal sebagai moral hazard (Demsetz et.al, 1997). Kedua, tidak adanya pengawasan dan pendisiplinan dari pemegang saham dan depositor membuat para manajer bank untuk mengejar kepentingan pribadinya (profit) dengan mengorbankan kepentingan pemegang saham (Berle \& Means, 1932; Jensen \& Meckling, 1976 dalam Demsetz et,al., 1997). 
Masalah keagenan yang terjadi di bank lebih kompleks bila dibandingkan dengan perusahaan non bank karena konflik kepentingan yang terjadi di bank bukan hanya antara agen dan pemilik tetapi juga antara agen dengan debitur atau kreditur maupun antara agen dengan regulator (Demsetz, 1997). Adanya peran dari regulator menyebabkan masalah keagenan pada perbankan lebih kompleks. Bank harus menjalankan aktivitas bisnisnya di bawah pengawasan bank sentral.

\section{Disiplin Pasar}

Salah satu aspek yang paling penting dalam meningkatkan keamanan dari simpanan masyarakat dan untuk mengurangi perilaku moral hazard yang dilakukan oleh pihak adalah dengan melakukan disiplin pasar. Disiplin pasar merupakan salah satu dari tiga pilar yang dibentuk oleh Basel Committee dalam meningkatkan kinerja dan transparansi perbankan. Ketiga pilar yang bangun oleh Basel Commitee dapat dilihat pada Gambar di bawah ini:

\section{Gambar I}

\section{Tiga Pilar Basel Commitee}

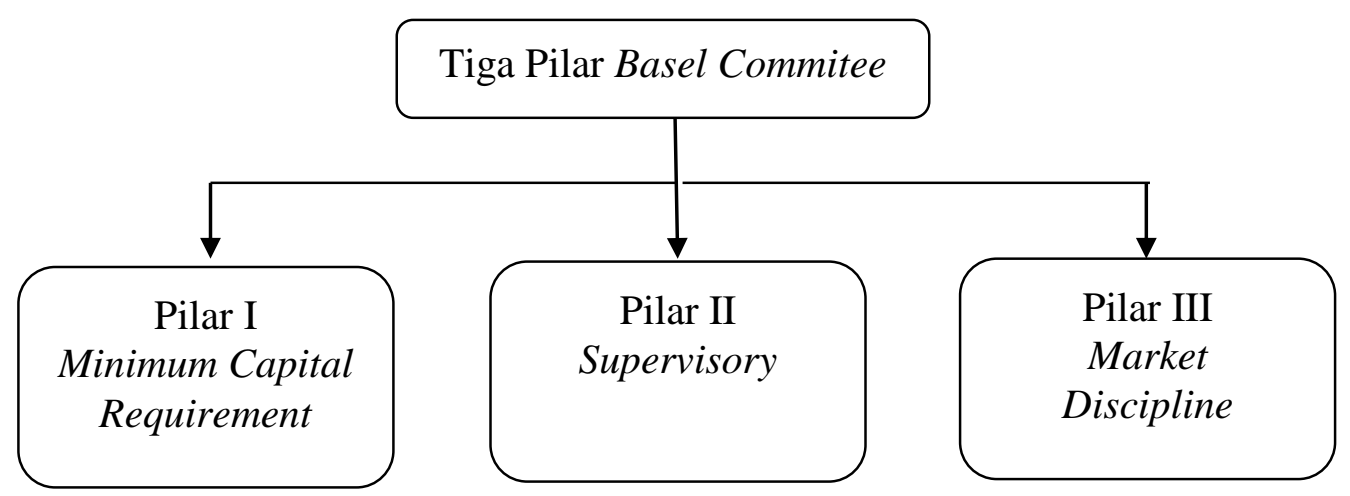

Sumber : Bank for International Settlement

Disiplin pasar menurut Berger (1991) adalah tindakan yang dilakukan oleh para deposan baik dengan menarik tabungannya dari bank atau dengan meminta tingkat suku bunga yang tinggi terkait dengan risiko yang diambil oleh perbankan. 
Disiplin pasar menjadi cara untuk mengurangi moral hazard yang dilakukan oleh perbankan. Disiplin pasar bisa dipahami dengan menggunakan agency theory. Menurut Jensen dan Meckling (1976) menyatakan bahwa masalah keagenan timbul karena pemilik (principal) dan manajer (agent) mempunyai kecenderungan untuk memaksimalkan keuntungan masing-masing. Dalam konteks perbankan, masalah ini timbul ketika pihak manajer menyalurkan dana para deposan ke pembiayaan usaha yang memiliki tingkat risiko yang tinggi atau melakukan kegiatan pemberian kredit secara agresif untuk memaksimalkan keuntungan yang pada akhirnya akan dinikmati oleh pihak bank saja. Menurut Trisnoningsih (2008) disiplin pasar harus ditegakkan jika lembaga penjaminan simpanan hendak dijadikan penyokong utama dalam proses mobilisasi dana masyarakat.

Berger (1991) mengidentifikasi keuntungan sosial dari peningkatan disiplin pasar, yaitu:

1. Disiplin pasar dapat mengurangi moral hazard.

2. Disiplin pasar dapat menekan bank untuk meningkatkan efisiensi.

3. Biaya sosial pengawasan bank dapat diturunkan.

4. Pengawasan oleh sektor swasta dapat memberikan infomasi kepada otoritas pengatur perbankan.

5. Investor memiliki informasi pasar, yang mana mereka terbiasa melakukan tindakan pendisiplinan, dapat mengurangi beban pengaturan dan pengawasan oleh otoritas moneter terhadap lembaga keuangan.

6. Disiplin pasar dapat melengkapi disiplin pengaturan yaitu dengan mengubah beban pembuktian oleh otoritas pengaturan perbankan kepada manajemen bank. Untuk itu, manajemen bank perlu menunjukkan kepada pasar bahwa banknya tidak mengambil risiko yang berlebihan.

Disiplin pasar dapat dikaitkan dengan informasi yang diperoleh deposan terkait kondisi suatu bank. Jika para deposan dengan mudah mendapatkan informasi tentang aktivitas dan risiko yang diambil oleh bank, maka para deposan akan dengan mudah menarik dananya jika suatu bank mengambil risiko berlebihan dan akhirnya ini akan 
mengurangi perilaku moral hazard yang dilakukan oleh bank. Tetapi sayangnya, informasi tentang aktivitas dan risiko yang diambil oleh bank sangat sulit untuk diperoleh, sehingga para deposan cenderung tidak menerapkan disiplin pasar pada bank. Kurangnya disiplin pasar juga diperparah dengan adanya regulasi dari pemerintah untuk menjamin dana masyarakat yang ada di suatu bank. Sehingga membuat para deposan tidak melakukan pendisiplinan terhadap dana mereka dan cenderung tidak mengawasi dananya di suatu bank.

\section{Moral hazard}

Pengambilan risiko perbankan yang bersifat spekulatif ketika bank tidak sehat diduga sebagai masalah moral hazard. Menurut Mishkin (2004), moral hazard adalah sebuah masalah yang disebabkan oleh adanya asymmetric information setelah transaksi antara bank dan kreditor terjadi. Moral hazard sering dipergunakan dalam bisnis asuransi yang menjelaskan kemungkinan pemegang asuransi dengan sengaja melakukan tindakan yang dapat merugikan barang yang diasuransikan dengan harapan akan mendapatkan klaim penggantian dari perusahaan asuransi. Istilah moral hazard kemudian banyak digunakan dalam perspektif perbankan yang merujuk pada perilaku pihak-pihak berkepentingan (stakeholder). Krugman (1999) menyebutkan bahwa konsep moral hazard telah luas digunakan untuk menjelaskan berbagai perilaku debitur (borrower) dan pemberi kredit (kreditur atau bank) yang berani mengambil risiko tinggi selama krisis keuangan yang terjadi Asia Tenggara pada tahun 1997-1998. Moral hazard merupakan dorongan untuk mengambil risiko berlebih yang biasanya dilakukan karena adanya kontrak penjaminan dan perilaku itu muncul karena pihak di dalam kontrak tersebut akan dilindungi dari kerugian (IADI, 2008).

Permasalahan yang terjadi di Indonesia adalah moral hazard dimana para pemilik bank bersama para pengelolanya tidak pernah mendapatkan hukuman dan ganjaran yang berarti akibat kelalaian dan keteledoran dalam membuat kebijakan fiskal menjadi lemah (Trisnoningsih, 2008) 
DaSilva dan Yoshitomi (2001) menyebutkan bahwa ada beberapa faktor yang menyebabkan terjadinya moral hazard yaitu:

1. Adanya regulasi prudensial perbankan yang lemah, sehingga bank dapat memberikan kredit yang sangat agresif, melakukan adverse selection dan moral hazard.

2. Adanya penjaminan simpanan, ini memberikan dorongan bank untuk memberikan kredit secara tidak hati-hati karena adanya jaminan simpanan oleh lembaga penjaminan simpanan

3. Adanya penjaminan kredit, maka akan menimbulkan bank sangat agresif memperluas pemberian kredit yang berisiko tinggi

4. Adanya bank sentral yang memberikan jaminan bagi bank, maka bank akan memberikan kredit secara agresif karena bank akan diselamatkan bila terjadi krisis secara sistemik, begitu juga bagi debitur akan berupaya meminjam melampaui kebutuhannya apabila Bank Sentral mengikuti kebijakan penyelamatan melalui program restrukturisasi kredit

5. Adanya lembaga asing yang menjamin pemberian kredit, maka bank asing akan memberikan kredit berlebihan apabila ada jaminan secara resmi atau tidak resmi dari lembaga tersebut di negaranya

6. Adanya pemberlakuan regulasi prudensial secara internasional, bank asing akan memberikan kredit yang berlebihan bila regulasi prudensial internasional belum diikuti atau belum ada pedoman yang jelas di negara tempat beroperasi bank tersebut, misalnya regulasi prudensial terhadap eksposur risiko.

7. Adanya undang-undang kepailitan yang lemah sehingga bisa disiasati oleh debitur jika terjadi kebangkrutan.

\section{PENUTUP}

Para deposan harusnya memiliki informasi tentang kondisi sebuah bank sehingga dapat mengawasi dananya di bank. Oleh karena itu, bank harus memberikan informasi yang jelas dan terbuka berkaitan dengan status kesehatan dan keuangan 
bank kepada publik agar masyarakat dapat merespon dengan tepat dan relevan. Disiplin pasar yang dilakukan oleh para deposan juga akan mengurangi pengambilan risiko berlebih yang dilakukan oleh pihak bank. Basel Comittee menjadikan disiplin pasar sebagai pilar ketiga dalam menjaga kesehatan dan keamanan bank bertujuan untuk mengurangi moral hazard yang terjadi pada perbankan.

\section{REFERENSI}

Basel Committee on Banking Supervision. (2001). Working Paper on Pillar 3-Market discipline. Bank for International Settlement.

Berger, A. N. (1991). Market Discipline in Banking. In Proceedings of a Conference on Bank Structure and Competition, Federal Reserve Bank of Chicago.

Bliss, R.\& Flannery, M. J. (2002). Market discipline in the governanceof U.S. bank holding companies: Monitoring vs influencing. European Finance Review, 6, 361-395.

Caldwell, G. (2007). Blueprints for a new global financial architecture. American Enterprise Institute. Washington DC.

DaSilva, L. A. P., \& Yoshitomi, M. (2001). Can "moral hazard" explain the Asian crises? ADB Institute Research Paper, 29, 1-80

Flannery, M. J. (2001). The faces of "market discipline." Journal of Financial Services Research, 20(2/3).107-119.

Flannery, M. J., \& Nikolova, S. (2004). Market discipline of US financial firms: Recent evidence and research issues. Market Discipline across Countries and Industries, 87-100.

Forssbæck, J. (2009). Essay on market discipline in comercial and central banking. Copenhagen Business School.

International Association of Deposit Insurers (2008). Deposit insurance coverage. Research and Guidance Commitee Internatioanl Assocaition of Deposits Insurers, (August), 1-45.

International Association of Deposit Insurers (2013). Enhanced Guidance for Effective Deposit Insurance Systems : Mitigating Moral Hazard. Research and 
Guidance Commitee Internatioanl Assocaition of Deposits Insurers, (May), 122.

Jensen, M. C., \& Meckling, W. H. (1976). Theory of the firm: Managerial behavior, agency costs and ownership structure. Journal of Financial Economics, 3(4), 305-360. http://doi.org/10.1016/0304-405X(76)90026-X

Keeley, M. C. (1990). Deposit Insurance, Risk, and Market Power in Banking. The American Economic Review, 80(5), 1183-1200. http://doi.org/10.2307/2006769

King, T.(2008). Discipline and liquidity in the interbank market. Journal of Money, Credit and Banking, 40(2-3), 295-317.

Krugman, P. (1998). What happened to Asia? In Conference Paper in Japan. Southwestern Publishing.

Martinez-Miera, D., \& Repullo, R. (2010). Does Competition Reduce the Risk of Bank Failure? The Review of Financial Studies, 23(0801), 3638-3664. Retrieved from http//www.jstor.org/stable/40865571

Mishkin, F. S. (2004). The Economic of Money, Banking, and Finacial Markets. PEARSON Addison Walley.

Nier, E., \& Baumann, U. (2006). Market discipline, disclosure and moral hazard in banking. Journal of Financial Intermediation, 15(3), 332-361. http://doi.org/10.1016/j.jfi.2006.03.001

Park, S., \& Peristiani, S. (2007). Are bank shareholders enemies of regulators or a potential source of market discipline? Journal of Banking \& Finance, 31(8), 2493-2515. http://doi.org/10.1016/j.jbankfin.2006.10.025

Trisnoningsih, M. D. (2008). Perlindungan hukum terhadap nasabah penyimpan dalam kaitannya dengan keberadaan undang-undang no. 24 tahun 2004 tentang Lembaga Penjaminan Simpanan pada PT Bank Rakyat Indonesia. Universitas Gadjah Mada. 